\title{
Performance Evaluation of Drainage System In Shire Endaslasse
}

\section{Town, Northern Ethiopia.}

Hadush Gebreyesus Gebreyohannes ${ }^{\mathrm{a},}$,, Ahmed Mohammed Degu ${ }^{\mathrm{b}}$

${ }^{a}$ Civil Engineering Department, Aksum Institute of Technology, Aksum University, Aksum, Ethiopia

${ }^{\mathrm{b}}$ Civil Engineering Department, Ethiopian Institute of Technology-Mekelle, Mekelle

University, Mekelle, Ethiopia. E-mail addresses; ahmed.mohammed@mu.edu.et

*Corresponding Author. Hadush Gebreyesus Gebreyohannes (HGG)

E-mail addresses; hadushaxum16@gmail.com

Cell no. +251919025002 , P.O.Box 1010

\begin{abstract}
Storm water drainage problem is one of the major challenges facing in Shire Endaslasse town, Ethiopia. In a town, Street flooding and over topping drainage system problems are occurring at the rainy season. This causes ponding which poses difficulties in ease of transportation and it hinders the day to day activity of the people. So, the study focuses on the performance of storm water drainage system in Shire Endaslasse town using Arc GIS and SWMM5.1. For this study, the primary data were collected by field survey and interview with the council body. Simulation results for storm events show that in some of the drainages systems in different regions of Shire Endaslasse town have flooded. During the field observation, the drainage structures are filled with solid wastes, in adequate inlet and outlet structures and some of the top element of the manhole has been broken this may causes a problem of aesthetic and healthy at large it may increase flood risk. The flooding risk in the drainage systems is very high due to the drainage system is undersized to cope with the current rainfall rates, but also is very limited to face the upcoming predicted rainfall.
\end{abstract}

Keywords: Urban Drainage, SWMM5.1, Land use, Hydraulic Performance, Shire Endaslasse. 


\section{Introduction.}

Across the world, flood is amongst the most devastating natural disaster, which caused loss of human lives and threats to infrastructure, the environment, and public services [1-3].The hydrological balance is affected by factors as the rapid growth of settlements and irregular urbanization on population increases and industrialization in developing countries, particularly in Ethiopia[4, 5].The evolution of land use is much related to urban development and increment of flood derived from it due to increasing proportion of the total land areas becomes covered with impermeable surface and decreasing the infiltration of water to the ground. Urbanization covers a large part of the ground with roofs, roads, and pavements and increases the rate of runoff. As a result of rapid urbanization and population growth, many towns are becoming hotspots for risk and disaster in Ethiopia [6].In the world, particularly in Ethiopia, the flood management is based on the concept of risk analysis with the likelihood of flooding assessed and consequences assessed regarding to damage and the magnitude of consequences [7].Urbanization enhances the frequency of highly flowing discharge of precipitation via conveyance systems that disregard soil moisture replenishment and ground water recharge[8].The runoff amount in urbanization is highly increased due to increase impermeable, resulting in overwhelming of designed capacity of the storm water drainage systems $[9,10]$.This is because all these phenomena has been happened flooding even small amount of rainfall from altered catchment of urban areas. Because of increasing in population density and development of urban infrastructure without paying due consideration to drainage aspects and increased in paved surface is the main causes of urban flooding $[11,12]$.As a result, floods have sever on the storm drains, deterioration of roads and blockages of storm drain due to solid waste, which increases the flood peaks and flood volumes $[13,14]$.To encounter these adverse urban water problems has habitually consisted of urban drainage infrastructures to minimize runoff accumulation. The urban drainage system is responsible for quickly removing storm water runoff through the drainage networks formed of a series of pipe and manholes connected to each other to the outlet point. However, these drainage networks do not have sufficient capacity to properly dispose the inflows, which may result flooding and surcharges along the network $[8,15]$.To evaluate floods of urban areas and checking performance of urban drainage systems, Engineers have been developed Hydrologic-Hydraulic models used to rainfall-runoff simulation process, and flood routing in the storm water network. Modeling of the urban flood of the drainage systems can be adopted by various software like 
SWMM, MIKE URBAN, HEC-HMS, HEC-RAS and RAFTS (runoff analysis and flow training simulation $[12,13,16]$. EP-SWMM is one of the most complete and widely used models throughout the world for planning, analysis, and design related to drainage systems with in urban areas. SWMM is more benefits than other urban watershed models because it used in large urban catchment and it demonstrates on drainage systems for storm water runoff and waste water management, considering both combined and sanitary sewer design and performance $[8,14,17-$ 20].Most models produces gross errors in simulating complex hydraulic and hydrologic systems due to range of practical issues. Mathematical models are a combination of runoff generation model and runoff model. The runoff produced software changes rainfall to surface runoff and translates in to the catchment outlet [21-23]. Due to availability and wider adopted used in the world to model the urban flood, SWMM is used to check the performance of the drainage systems for this investigation. Shire Endaslasse town is similar to many Ethiopian towns; rapidly expansion on the surface has not been accompanied by suitable expansion and upgrades of the storm urban drainage networks. As the town has expanded, the current network has become unsuitable, leading to more frequency surface water flooding generated from rainfall. Therefore, Shire Endaslasse town usually suffer from urban storm water drainage management problem such as overtopping and flooding the drainage network as shown in figure 1 and the existed urban storm water drainage infrastructure has not been constructed and provided at a city wide network basis and the inlet as well as outlet structures have constructed with no due consideration to the existing drainage system. Hence, there is a need of studying the performance evaluation of drainage system in Shire Endaslasse town, northern Ethiopia.

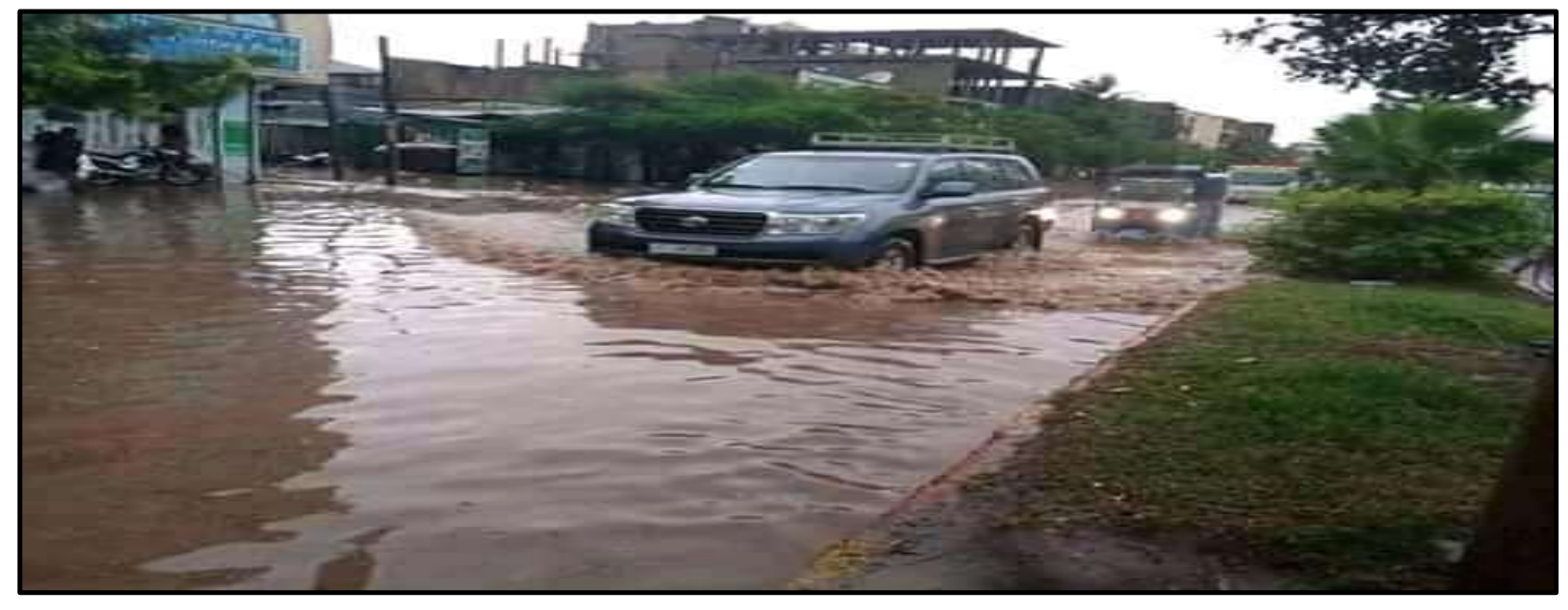

Fig.1.Some of the flooded drainage network in Shire Endaslasse town 


\section{MATERIAL AND METHODS}

\subsection{Study area Description}

The town of Shire Endaslasse is located in northern part of Ethiopia. Its administrative location is Tigray National Regional State, North western zone. While, its absolute geographic coordinates are $422795 \mathrm{~m} \mathrm{E}$ and $1559778 \mathrm{~m} \mathrm{~N}$, the average elevation of the town is approximately 1923 m.a.s.1. The town is found about $1106 \mathrm{kms}$ faraway from Addis Ababa via Mekelle-Adigrat through Amhara region way and about $300 \mathrm{kms}$ from Mekelle, regional capital, to Northwest of the region. The town occupies a total area of 1512.5 hectare's.

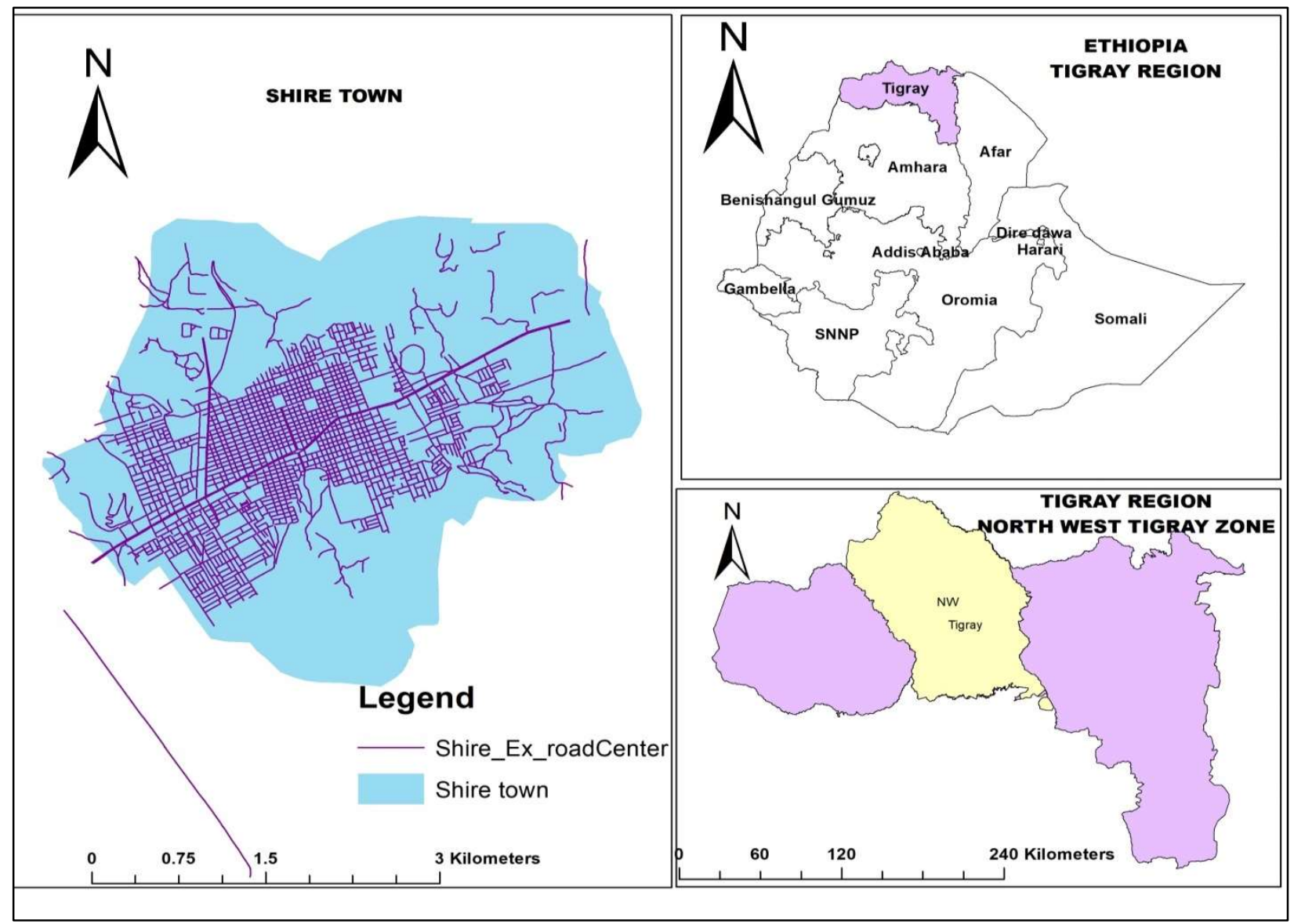

\section{Fig.2. Location map of the study area}

Shire Endaslasse town is characterized by a highly flat relief with small hills. The north and western parts of the town are surrounded by hills, ridges and mountains while the southern part remains flat to gentle landscape as shown in figure 3. The northern part of the town has a sloppy landscape. The elevation varies from 1980 m.a.s.1 at the gorges to 2440 m.a.s.1 and slope varies from $0.5 \%$ to $3.5 \%$. 


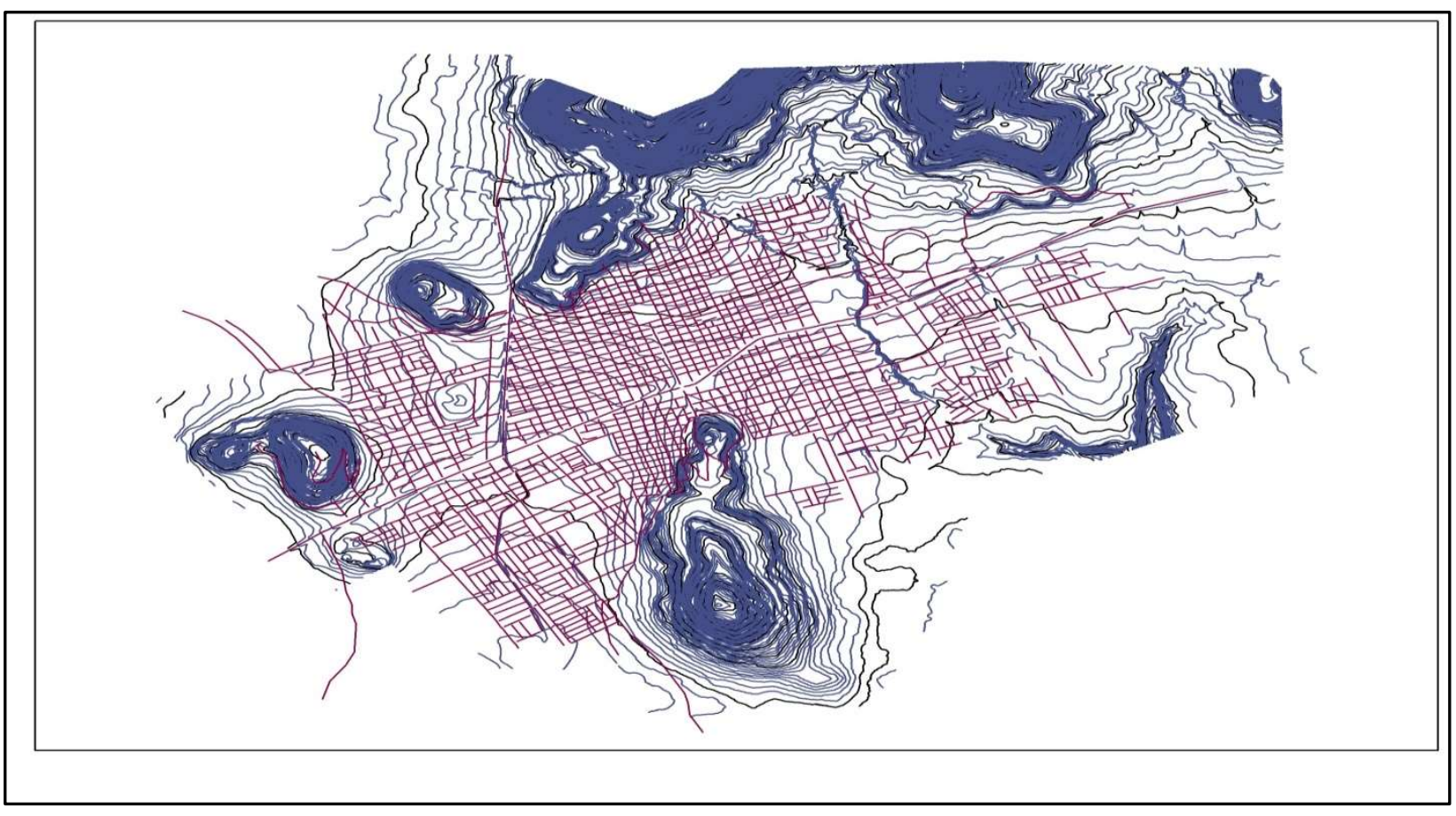

Figure 3: Contour of the study area

\subsubsection{Climate}

Shire Endaslasse is found within the WoinaDega Zone where altitude is from 1980-2440 m.a.s.1. Temperature data were obtained from the nearby Shire Endaslasse station that is located at an average distance of $5 \mathrm{~km}$ from the area. The mean minimum monthly temperature is expressed between $13.1^{\circ} \mathrm{C}$ in September and $18.7^{\circ} \mathrm{C}$ in May and the mean maximum monthly temperature range from $19^{\circ} \mathrm{C}$ to $32^{\circ} \mathrm{C}$ in May. Mean annual rainfall of the town is estimated to be $600 \mathrm{~mm}$ that about $80 \%$ of the rainfall is received from mid-June to midSeptember with little rain from December to January. The highest rainfall is usually received in July to August where it goes on decreasing to the month of September.

\subsection{Data Collection}

\subsubsection{Surveying Data collection}

In this study, a general field survey of the existing condition of the drainage structures was employed. For the hydraulic analysis of the drainage system of shire Endaslasse town, have collected survey data of the junction or nodes such as Invert elevation of for each junction, coordinates and segment of the drainage was taking as shown figure 4 . 


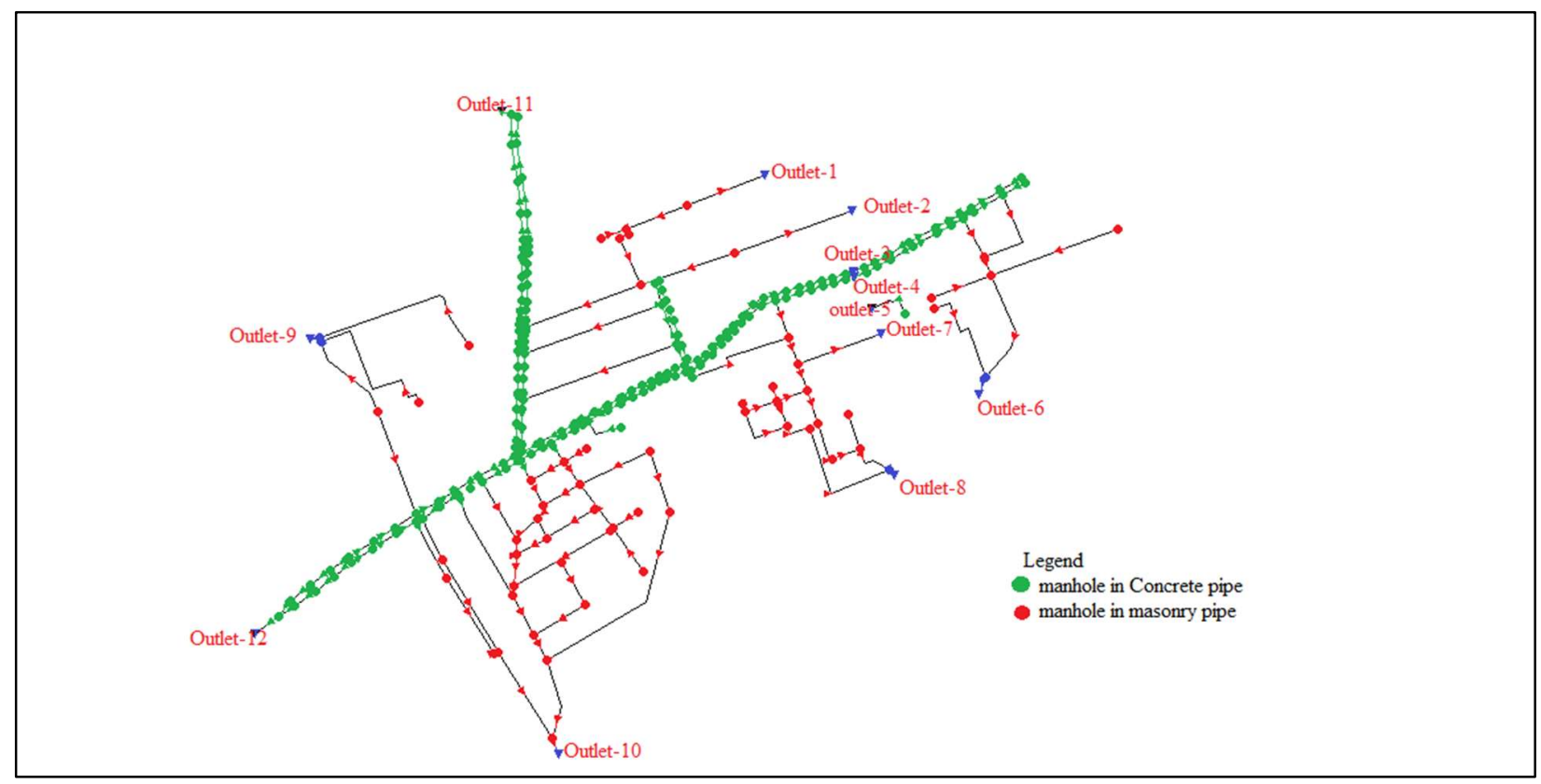

Fig.4. surveying data collected drainage of Shire Endaslasse town

\subsubsection{Rainfall Data}

Rainfall data were obtained from Ethiopian Meteorological Services Agency which is nearby Shire Endaslasse station located at an average distance of $5 \mathrm{~km}$ from the area. Available rainfall data on this station has been collected and analyzed in order to prepare the necessary depth or intensity input data for peak discharges computation. For this study, 38 year historic observation data is used to calculate the peak drainage storm water of the Shire Endaslasse town. Due to shortage of recorded rainfall data, it is difficult to develop the IDF curve for this study. Therefore, the Ethiopian road authority developed IDF is adopted for this study.

\subsubsection{Urban storm water drainage lines}

There are two types of urban drainage lines in Shire Endaslasse town. Namely: concrete and masonry drains, which are constructed by the municipality and Ethiopian Roads Authority in order to safely discharge the flood generated within the town in the process of urbanization. But, as observed during data collection through field survey with the help of road net-work, these drains becomes causes of flooding by collecting rain water from various parts of the drainage system. These drains totally concentrated on asphalt and on non-asphalt roads. The asphalt roads provided with manmade drainage ditches of closed types either in both sides or in one side and cover $30855 \mathrm{~m}$ of the drainage lines of the town. The gravel roads provided with manmade drainage ditches either closed or open rectangular masonry and cover 9390 and $2500 \mathrm{~m}$ 
respectly. Moreover, Cobble stone side drains also provided with the cobble stone road. During field survey the side drains which are provided at both sides of the cobble stone roads cannot carry flood other than the flood which is generated on the cobble road surface and it is observed that in some cobblestone roads even no side drain is provided. The existed drainage structure is shown in figure 5.

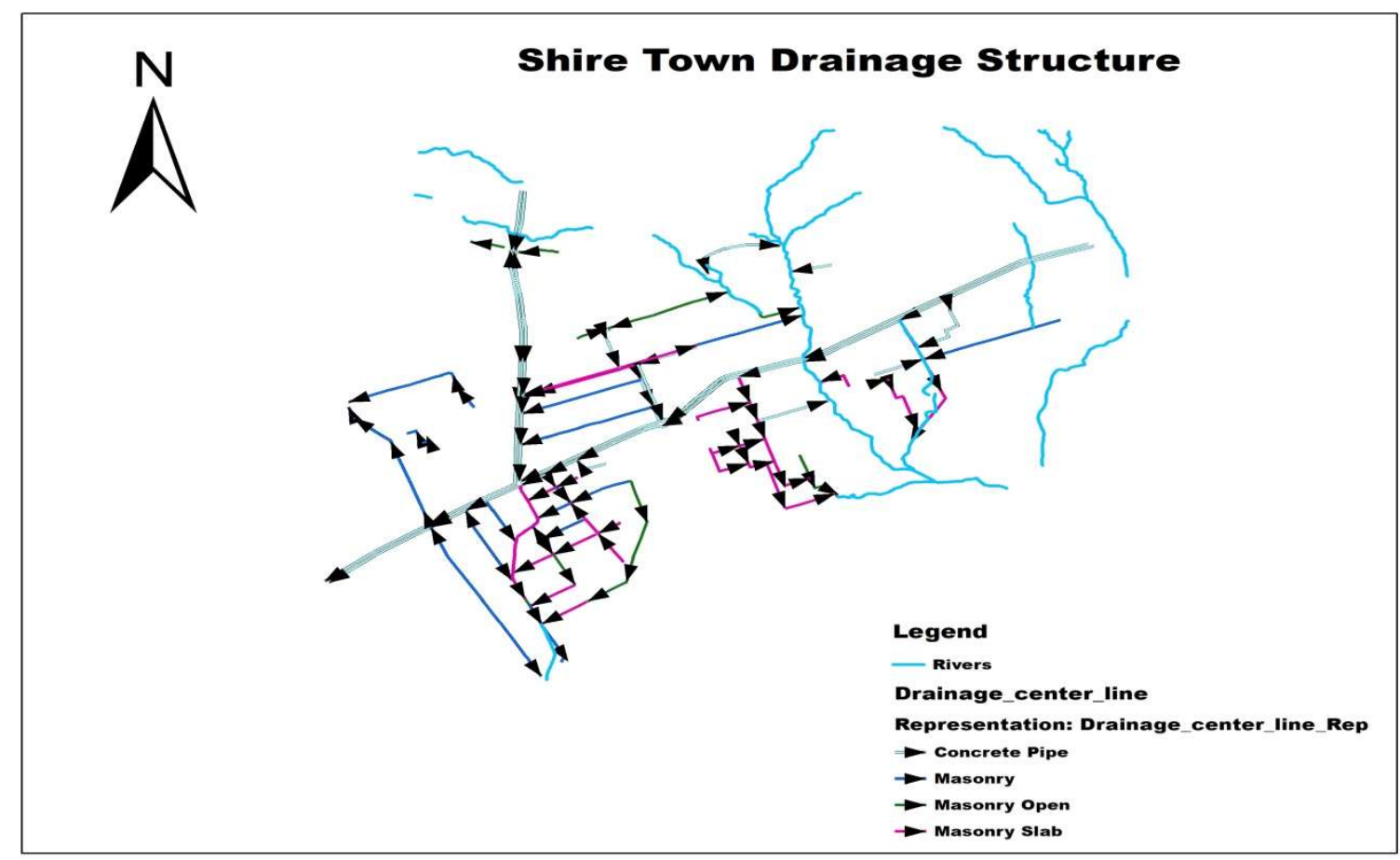

Fig.5.The existed drainage structures of Shire Endaslasse town.

\subsection{Land use And Land cover}

The land use land cover is extracted from the master plan of Shire Endaslasse town and categorized of different land use with ArcGIS analysis and where a land use layer displaying commercial, residential, green, service, road, administrative and industry areas considered calculating the maximum flood. Land use have a direct impact on the flood amount, speed and potential to create damage that is why the study gives notice for land use and land cover of the catchment.

\subsection{Urban Runoff Model}

The storm water management model $(5.1)$ [18, 19]is a comprehensive computer model for simulation of urban runoff quantity and quality in storm and combined sewer systems from urban areas. The SWMM model has been used in numerous aspects to assess the effects of storm water 
management based on traditional drainage systems. To apply SWMM in urban areas, depth of depression storage on impervious and pervious area parameters and Manning roughness coefficient has been extracted from the values suggested by ASCE (1992) and McCuen et al (1996) and ASCE (1982) manuals[24-26]. Manning's roughness coefficients for the impervious area (N-Imperv) is 0.012 , the pervious area (N-Perv) is 0.1 ; the depth of depression storage on the impervious and pervious area was $3.2 \mathrm{~mm}$ and $6.6 \mathrm{~mm}$, respectively[24, 25].The maximum infiltration rate was $75 \mathrm{~mm} / \mathrm{h}$, while the minimum rate was $3.81 \mathrm{~mm} / \mathrm{h}$. To simulate the generation of runoff, other parameters are determined with Arc GIS and from the field survey. The required input data to define the properties of the sub catchments is set by the choice of one hydrological model. Green Ampt method and Kinematic Wave are selected for infiltration and routing model[27]. The flow conditions of the drainage systems are performed by solving the Saint Venant equations in many points of the pipes and manholes.

$$
\frac{\partial Q}{\partial x}+\frac{\partial A}{\partial t}=0
$$

Where: $\mathrm{Q}=$ the discharge $\left(\mathrm{m}^{3} \mathrm{~s}^{-1}\right), \mathrm{A}=$ the cross sectional area of flow $\left(\mathrm{m}^{2}\right), \mathrm{x}=$ the distance along the channel $(\mathrm{m})$, and $\mathrm{t}=$ the $(\mathrm{h})$. The momentum equation is given by:

$$
\frac{1}{g} \frac{\partial V}{\partial t}+\frac{V}{g} \frac{\partial V}{\partial x}+\frac{\partial h}{\partial x}+\left(S_{f}-S_{o}\right)=0
$$

Where: $\mathrm{g}=$ acceleration due to gravity $\left(\mathrm{m} \cdot \mathrm{s}^{-2}\right), \mathrm{V}=$ the velocity $\left(\mathrm{m} \cdot \mathrm{s}^{-1}\right), \mathrm{h}=$ the depth of flow $(\mathrm{m}), S_{f}$ and $S_{o}=$ friction and bed slopes $\left(\mathrm{m}, \mathrm{m}^{-1}\right)$ respectively.

The rainfall is initial abstract in surface ponding, interception by flat roofs and vegetation, and surface wetting, but the remaining is changed to surface runoff.

The flow across the sub catchment's surface behaves as if it were uniform flow within a rectangular channel of width, the Manning equation can be used to express the runoff's volumetric flow rate $\mathrm{Q}(\mathrm{cms})$ as:

$$
\mathrm{Q}=\frac{1}{n} s^{1 / 2} R_{x}{ }^{2 / 3} A_{x}
$$

Where:-

$\mathrm{n}$-is the surface roughness coefficient, $\mathrm{S}$ the average slope of the sub catchment $(\mathrm{m} / \mathrm{m})$, Ax- the area across the sub catchment's width through which the runoff flows $\left(\mathrm{m}^{2}\right)$, and $\mathrm{Rx}$ - is the hydraulic radius (m). 


\section{Sub catchment.}

Based on urban drainage, the sub-catchment was identified. The study area was divided into sub catchment based on Topographic map, building blocks, direction of flow in drainage.61 sub catchment were determined in figure(6).

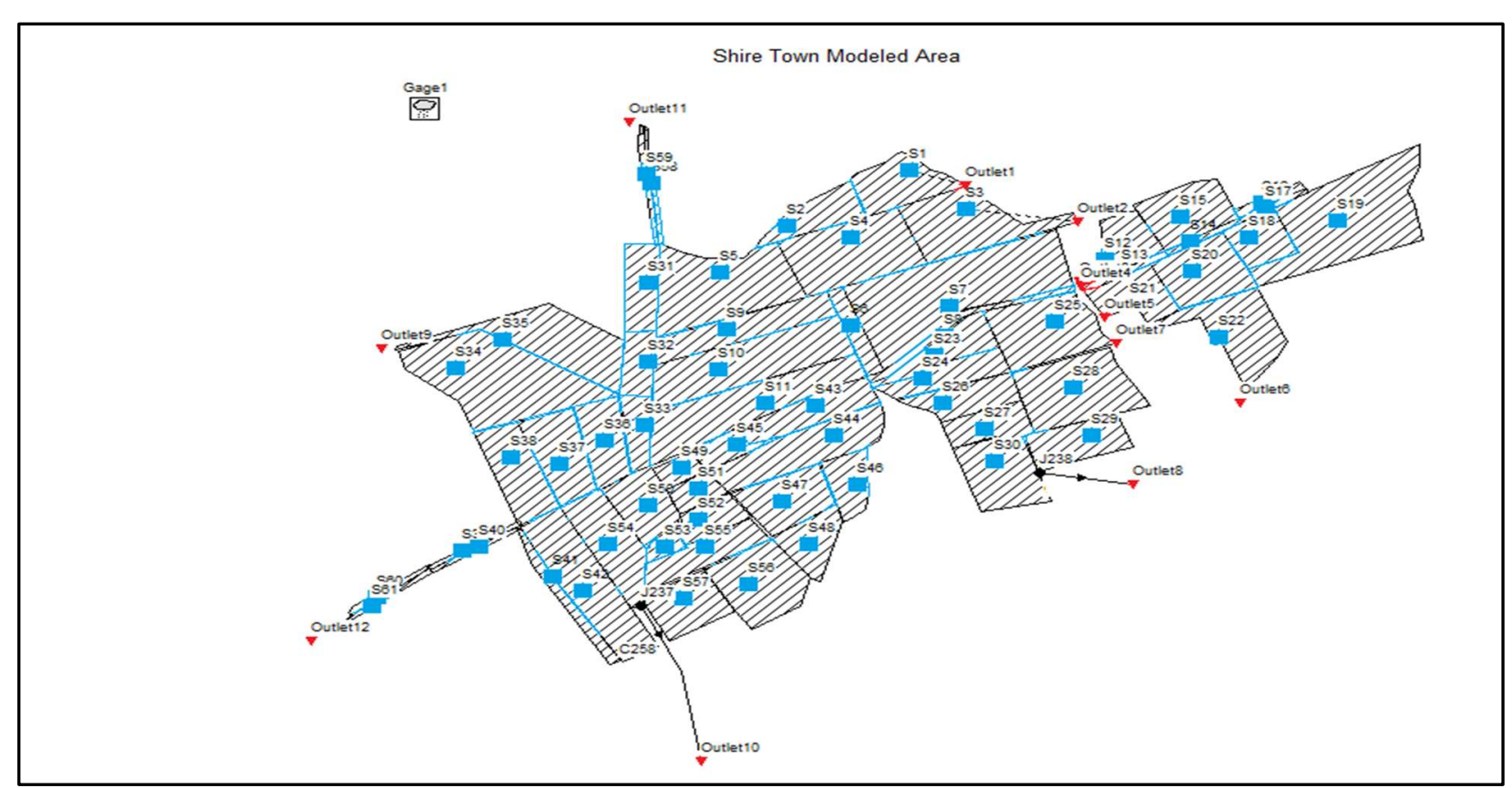

Fig.6. Shire Endaslasse town modeled area sub catchments.

\section{RESULTS AND DISCUSSIONS}

\subsection{Spatial Setting, Land Use and Land Cover map}

Land uses in Shire Endaslasse towns are defined as spatially specific different organized human activities in an urban context. Like many other middle level Ethiopian towns and urban centers, Shire Endaslasse existing settlement pattern also significantly proportioned residential uses as its major urban activity as shown in the figure 7. 


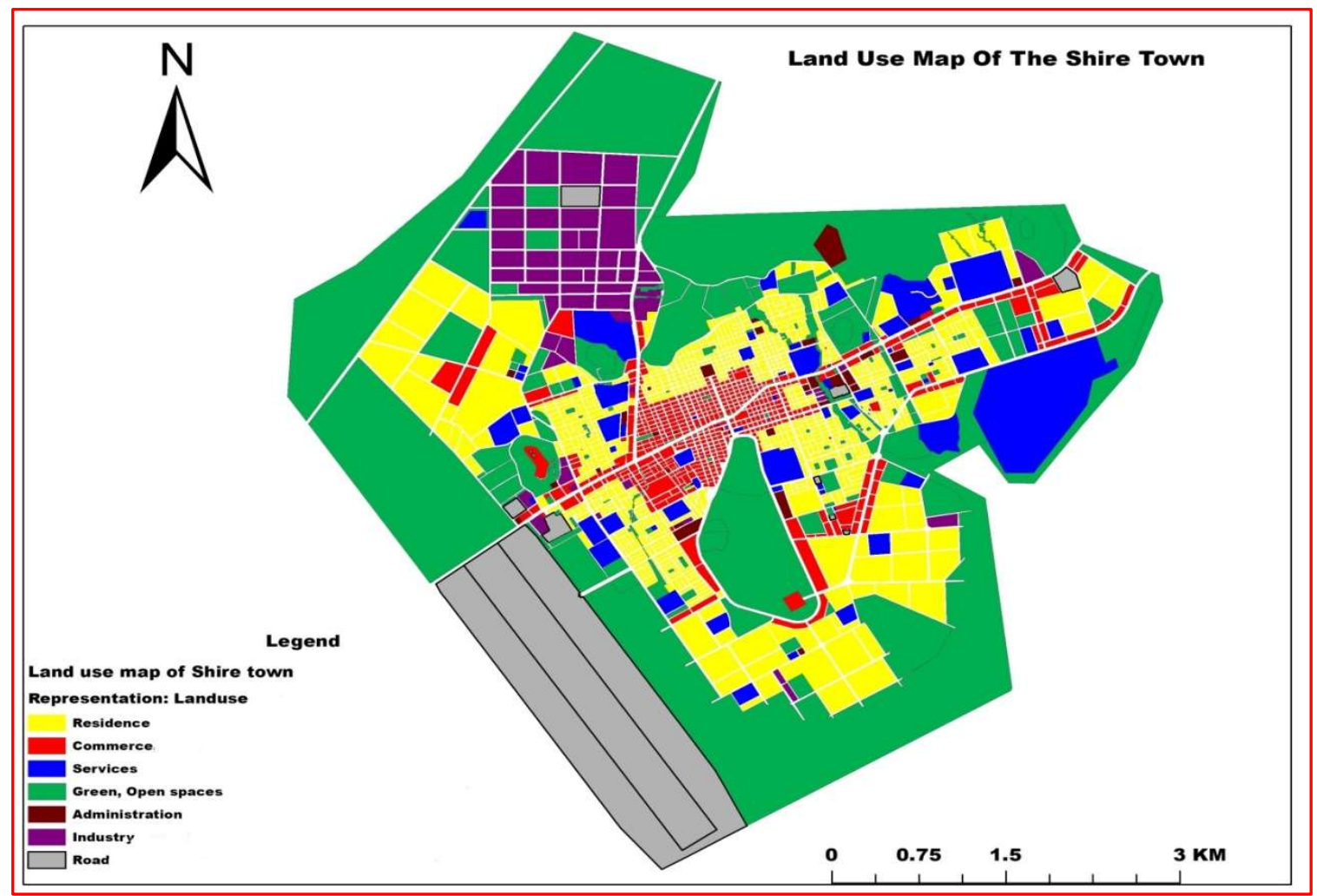

Fig.7.Land use modeled area of Shire Endaslasse town

\subsection{Urban Runoff Model Results.}

Different case scenarios have been considered in this study to obtain a fully understanding of the system performance under multiple working conditions. Firstly, the model had been run with the continuous rainfall events to analyze the current performance, as shown in Table 1.

Table1. Peak runoff at each sub catchment

\begin{tabular}{lllllll}
\hline \multicolumn{5}{c}{ Sub catchment Runoff } \\
\hline Sub & Area & Total preci. & Total & Total & Total & Peak Runoff \\
catchment & (hact.) & $(\mathrm{mm})$ & Evap. $(\mathrm{mm})$ & Infil $(\mathrm{mm})$ & Runoff10^6 Itr & CMS \\
S2 & 13.45 & 197.2 & 0 & 4.77 & 15.84 & 1.5 \\
S4 & 35.59 & 197.2 & 0 & 5.51 & 34.42 & 3.47 \\
S5 & 42.58 & 197.2 & 0 & 2.7 & 44.58 & 4.73 \\
S9 & 21.4 & 197.2 & 0 & 2.17 & 20.29 & 2.29 \\
S10 & 40.02 & 197.2 & 0 & 2.26 & 23.23 & 3.07 \\
S11 & 36.98 & 197.2 & 0 & 1.99 & 28.59 & 3.5 \\
S31 & 13.47 & 197.2 & 0 & 1.65 & 9.61 & 1.21 \\
S32 & 19.61 & 197.2 & 0 & 1.64 & 7.33 & 0.91 \\
S33 & 8.99 & 197.2 & 0 & 1.62 & 7.6 & 0.91 \\
S34 & 49.4 & 197.2 & 0 & 5.8 & 22.02 & 2.86 \\
S35 & 33.2 & 197.2 & 0 & 6.95 & 14.47 & 1.73 \\
S36 & 16.36 & 197.2 & 0 & 3.24 & 16.66 & 1.71 \\
\hline
\end{tabular}




\begin{tabular}{lllllll}
\hline S37 & 19.74 & 197.2 & 0 & 3.31 & 18.41 & 2.03 \\
S38 & 20.52 & 197.2 & 0 & 3.31 & 19.39 & 2.21 \\
S39 & 1.77 & 197.2 & 0 & 1.44 & 2.4 & 0.22 \\
S40 & 2.08 & 197.2 & 0 & 1.54 & 2.36 & 0.25 \\
S41 & 7.24 & 197.2 & 0 & 1.7 & 3.49 & 0.48 \\
S42 & 33.66 & 197.2 & 0 & 3.99 & 21.51 & 2.66 \\
S43 & 16.96 & 197.2 & 0 & 2.08 & 19.57 & 2 \\
S44 & 28.22 & 197.2 & 0 & 2.22 & 21.45 & 2.63 \\
S45 & 6.79 & 197.2 & 0 & 2.06 & 8.12 & 0.81 \\
S46 & 10.64 & 197.2 & 0 & 5.69 & 7.63 & 0.85 \\
S47 & 19.28 & 197.2 & 0 & 5.23 & 23.2 & 2.18 \\
S48 & 12.85 & 197.2 & 0 & 6.65 & 11.34 & 1.15 \\
S49 & 4.82 & 197.2 & 0 & 2.75 & 4.36 & 0.49 \\
S50 & 15.91 & 197.2 & 0 & 3.35 & 13.38 & 1.53 \\
S51 & 6.2 & 197.2 & 0 & 5.46 & 6.33 & 0.63 \\
S52 & 9.15 & 197.2 & 0 & 8.36 & 6.55 & 0.69 \\
S53 & 3.44 & 197.2 & 0 & 5.27 & 4.04 & 0.38 \\
S54 & 22.58 & 197.2 & 0 & 3.38 & 16.75 & 2.01 \\
S55 & 15.1 & 197.2 & 0 & 5.8 & 6.21 & 0.81 \\
S56 & 25.4 & 197.2 & 0 & 5.79 & 11.5 & 1.47 \\
S57 & 16.85 & 197.2 & 0 & 5.65 & 13.34 & 1.43 \\
S58 & 2.48 & 197.2 & 0 & 1.03 & 2.32 & 0.27 \\
S59 & 2.87 & 197.2 & 0 & 1.02 & 2.88 & 0.32 \\
S60 & 1.66 & 197.2 & 0 & 1.43 & 2.28 & 0.21 \\
S61 & 1.91 & 197.2 & 0 & 0.97 & 2.26 & 0.23 \\
\hline
\end{tabular}

Moreover, different local improvements in the system nearby the properties which have been flooded in previous years were modeled and analyzed. The above table 1 showed the calculation of peak runoff for the sub catchments which are the most runoff producers. Those subcatchments are the main source of the runoff to become the drainage network flooded.

\subsection{Network simulation}

The drainage systems modeled to cope with a 25 years return period rainfall in terms of water level below the surface in drainage systems. This implies that the flooding risk must be verified in the nodes (manholes) in the systems, whereas water level at each manhole is checked independently with a longitudinal profile in drainage systems which are connected. The general network performance is determined by maximum water flow production. The water elevation profile in the manhole was over flooded as shown in the figure 8 , and 9. 


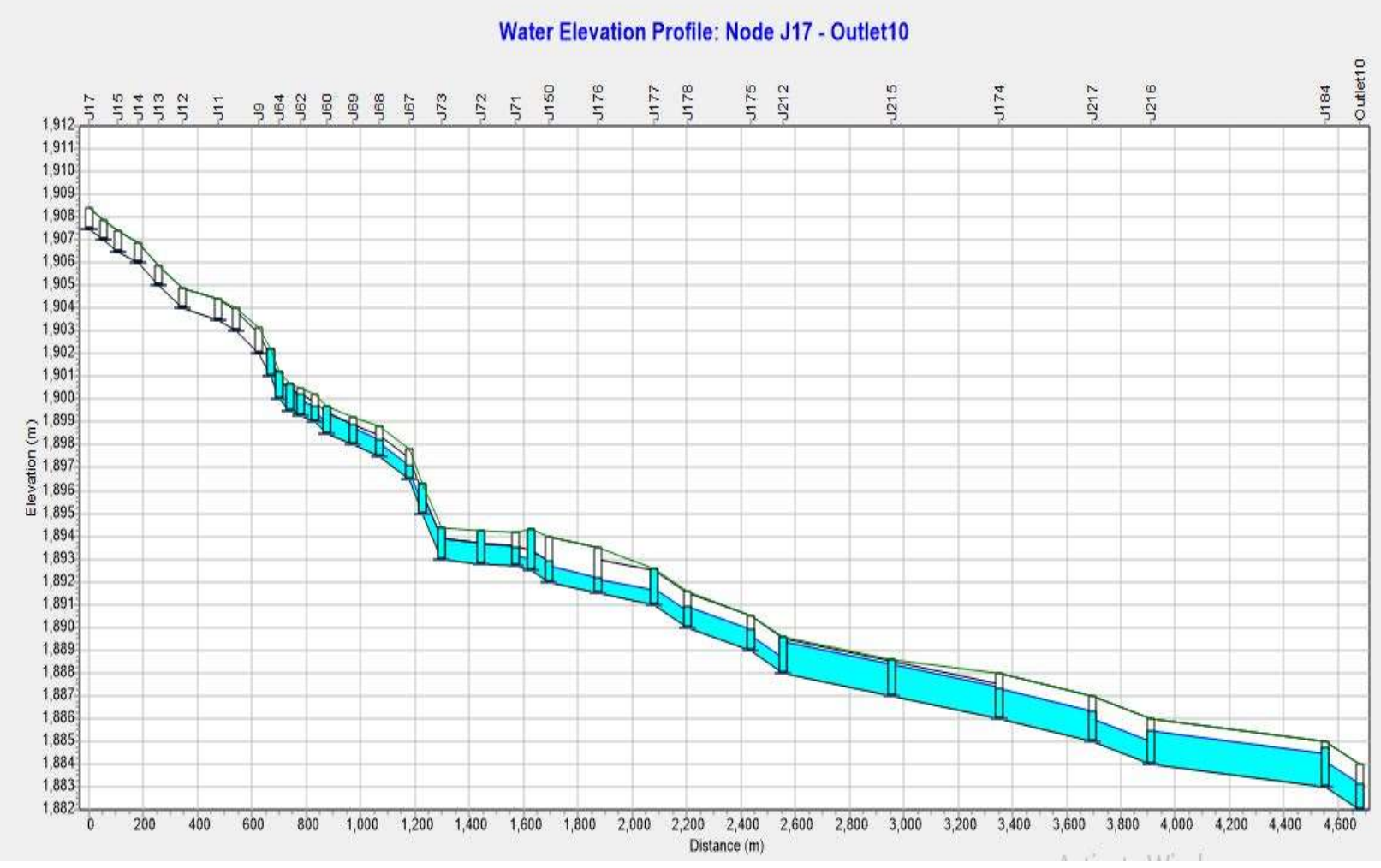

Fig.8. Water elevation profiles of the drainage network sections under flooding

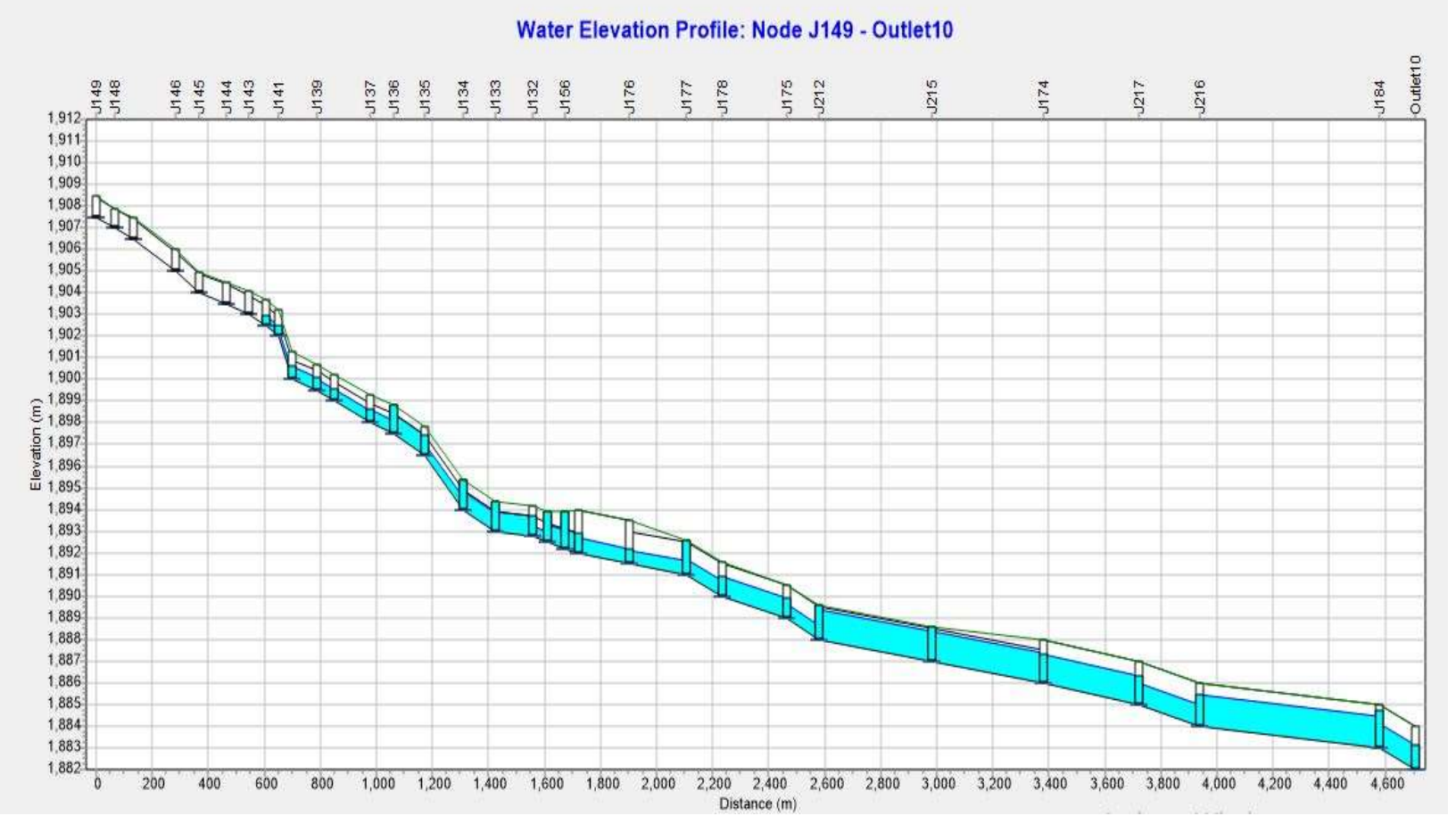

Fig.9. Water elevation profiles of the drainage network sections under flooding 
And also total average flow $29.406 \mathrm{~m}^{3} / \mathrm{s}$ and total maximum peak flow to outfall $49.76 \mathrm{~m}^{3} / \mathrm{s}$ were occurred from all 61 sub catchment. Detail show on table 2.

Table 2.Total average flow and total maximum peak flow at each outlet

\begin{tabular}{lllll}
\hline \multicolumn{5}{c}{ Outfall loading } \\
\hline Outfall node & $\begin{array}{l}\text { Flow } \\
\text { freq.(\%) }\end{array}$ & $\begin{array}{l}\text { Avg. flow } \\
(\mathrm{cms})\end{array}$ & $\begin{array}{l}\text { max.flow } \\
(\mathrm{cms})\end{array}$ & $\begin{array}{l}\text { Total volume } \\
10^{\wedge} 6 \text { Itr }\end{array}$ \\
Outlet 1 & 83.19 & 1.046 & 1.872 & 18.773 \\
Outlet 2 & 83.19 & 1.572 & 2.868 & 28.21 \\
Outlet 3 & 82.64 & 0.622 & 1.243 & 11.075 \\
Outlet 4 & 82.5 & 0.182 & 0.308 & 3.234 \\
Outlet 5 & 83.19 & 0.388 & 0.879 & 6.955 \\
Outlet 6 & 81.94 & 4.382 & 8.762 & 77.442 \\
Outlet 7 & 0 & 0 & 0 & 0 \\
Outlet 8 & 79.44 & 4.32 & 5.739 & 74.046 \\
Outlet 9 & 82.78 & 1.995 & 4.58 & 35.606 \\
Outlet 10 & 76.81 & 14.363 & 22.438 & 237.922 \\
Outlet 11 & 82.78 & 0.285 & 0.587 & 5.086 \\
\hline Outlet 12 & $\mathbf{8 1 . 6 7}$ & $\mathbf{0 . 2 5 1}$ & $\mathbf{0 . 4 4}$ & $\mathbf{4 . 4 1 7}$ \\
\hline
\end{tabular}

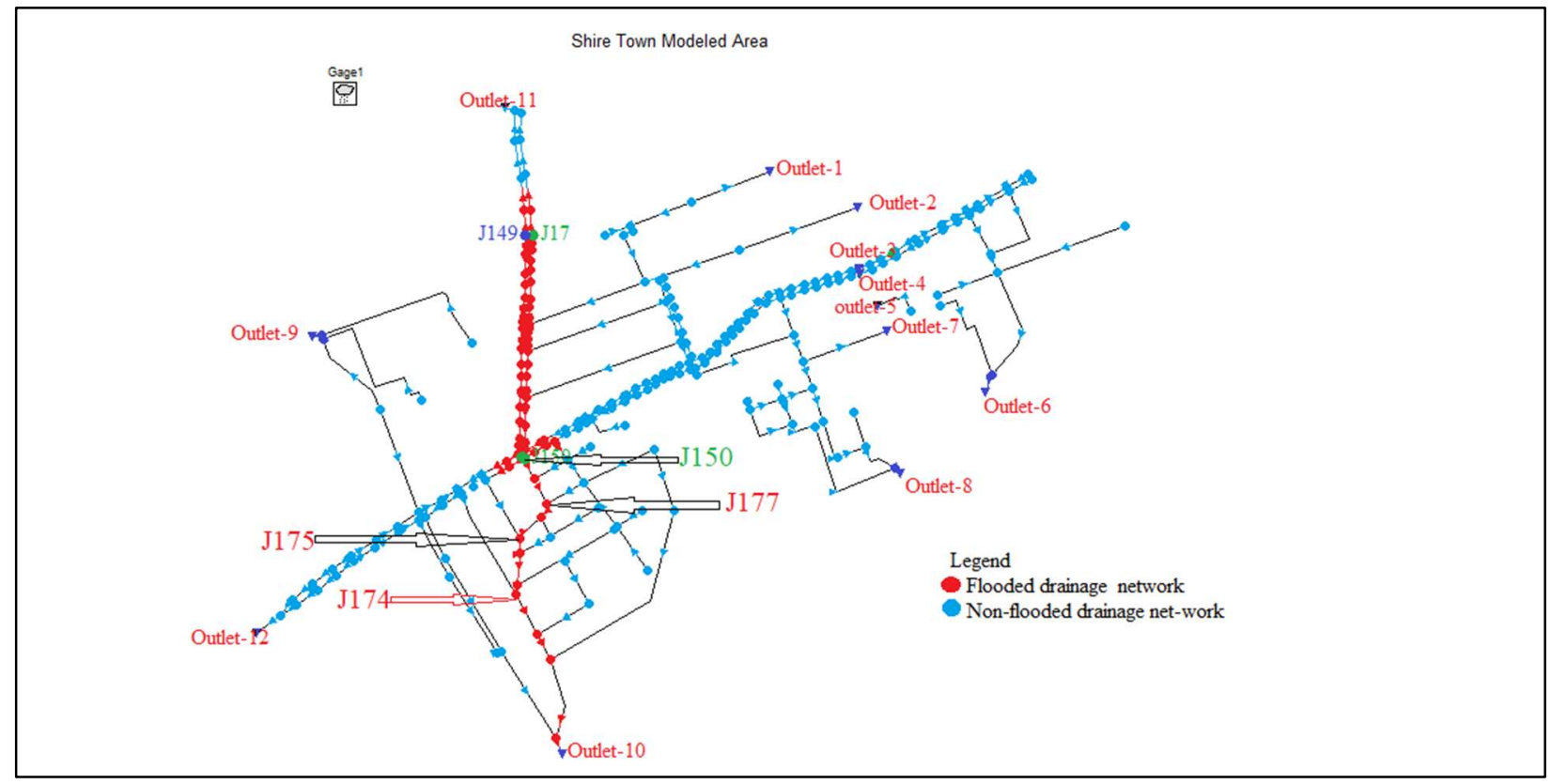

\section{Fig.10.Flooded Junctions and conduits of Shire Endaslasse town}

As is seen in the above figure 10, this area had a severe water gathering in the street and it flooded to nearby houses. In this area, 30 commercial buildings and 10 residential houses suffered from flooding. When concluded that, the flooding is much due to undersized of the 
drainage pipe and slopes of the consecutive nodes and due to unmanageable entrance of solid waste materials to the manhole.

Table 3: Water flow profile of flooded junctions

\begin{tabular}{llllll}
\hline \multicolumn{7}{l}{ Node flooding } & & & \\
\hline Node & Hours & maximum & Day of maxi. & Hours of maxi. & Total flood \\
& flooded & rate $(\mathrm{cms})$ & flooding & flooding & volume $10^{\wedge} 6$ ltr \\
J60 & 4.21 & 2.216 & 0 & $6: 00$ & 18.619 \\
J63 & 4.16 & 1.653 & 0 & $2: 32$ & 20.194 \\
J64 & 3.61 & 1.572 & 0 & $3: 09$ & 15.27 \\
L66 & 1.52 & 1.165 & 0 & $6: 00$ & 3.176 \\
J69 & 0.07 & 0.081 & 0 & $1: 52$ & 0.012 \\
J70 & 3.03 & 2.488 & 0 & $6: 00$ & 14.195 \\
J72 & 4.43 & 0.122 & 0 & $1: 37$ & 1.1 \\
J73 & 4.44 & 2.813 & 0 & $5: 01$ & 30.136 \\
J133 & 2.63 & 1.166 & 0 & $5: 56$ & 6.344 \\
J134 & 0.6 & 0.171 & 0 & $5: 56$ & 0.202 \\
J136 & 0.52 & 0.231 & 0 & $6: 00$ & 0.223 \\
J156 & 0.95 & 0.161 & 0 & $6: 00$ & 0.312 \\
J158 & 1.76 & 0.452 & 0 & $6: 00$ & 1.49 \\
J159 & 1.98 & 0.73 & 0 & $6: 00$ & 2.755 \\
J160 & 2.83 & 1.304 & 0 & $6: 00$ & 7.391 \\
J183 & 1.94 & 1.498 & 0 & $6: 00$ & 5.338 \\
J194 & 0.08 & 0.016 & 0 & $6: 00$ & 0.002 \\
J201 & 2.78 & 0.992 & 0 & $6: 00$ & 5.736 \\
J204 & 2.11 & 2.548 & 0 & $6: 00$ & 9.985 \\
J212 & 2.11 & 2.002 & 0 & $6: 00$ & 10.731 \\
J215 & 2.19 & 1.987 & 0 & $6: 00$ & 10.976 \\
\hline
\end{tabular}

The water profile plot and tabulated is obtained for the junction in between J17 and J149 to outlet 10 as shown in the above table 3 . The simulation status shows that sections between these junctions are the most surcharged (flooded).

\section{Conclusions}

This study evaluated the performance of storm water drainage system of Shire Endaslasse town and peak runoff in all sub catchments and outfalls. The hydrology was simulated using EPA SWMM5 for all sub catchments of the drainage system of Shire Endaslasse town. According to simulation some of the modeled drainage systems on the drainages system are flooding. And also total average flow $29.406 \mathrm{~m}^{3} / \mathrm{s}$ and total maximum peak flow to outfall $49.76 \mathrm{~m}^{3} / \mathrm{s}$ were 
occurred from all $61 \mathrm{sub}$ catchment. The flooding risk in the drainage systems is very high due to the drainage system is undersized to cope with the current rainfall rates, but also is very limited to face the upcoming predicted rainfall. The main road is a commercial land use type and produces more solid waste materials to each near manholes. The cause for flooding problem at the study area are construction and/or design problems and drainage poor management.

\section{Declarations}

\section{Authors Contribution Statement}

HGG. Conceptualized the research, performed the formal analysis, and wrote the paper under the supervision of AM. All authors revised the paper and agreed on the final version of the paper.

\section{Funding Statement}

Funding was provided by Aksum University.

\section{Competing Interest Statement}

The authors declare no conflict of interest.

\section{Additional Information}

No additional information is available for this paper.

\section{Acknowledgment}

The authors would like to acknowledge the Ethiopian metrological agency and Shire Endaslasse town urban development bureau for providing necessary data for the research.

\section{References}

1. Afifi, Z., et al., Residential flood loss assessment and risk mapping from high-resolution simulation. Water, 2019. 11(4): p. 751.

2. Xing, W., et al., Layout effects and optimization of runoff storage and filtration facilities based on SWMM simulation in a demonstration area. Water Science and Engineering, 2016. 9(2): p. 115-124.

3. Ye, S., et al., Understanding flood seasonality and its temporal shifts within the contiguous United States. Journal of Hydrometeorology, 2017. 18(7): p. 1997-2009.

4. İcaga, Y., E. Tas, and M. Kilit, Flood inundation mapping by GIS and a hydraulic model (HEC RAS): A case study of Akarcay Bolvadin subbasin, in Turkey. Acta Geobalcanica, 2016. 2(2): p. 111-118. 
5. Yang, B., T. Xu, and L. Shi, Analysis on sustainable urban development levels and trends in China's cities. Journal of Cleaner Production, 2017. 141: p. 868-880.

6. Kang, L., et al., Evaluation of return period and risk in bivariate non-stationary flood frequency analysis. Water, 2019. 11(1): p. 79.

7. Miller, J.D. and M. Hutchins, The impacts of urbanisation and climate change on urban flooding and urban water quality: A review of the evidence concerning the United Kingdom. Journal of Hydrology: Regional Studies, 2017. 12: p. 345-362.

8. Jato-Espino, D., et al., Rainfall-runoff simulations to assess the potential of SuDS for mitigating flooding in highly urbanized catchments. International journal of environmental research and public health, 2016. 13(1): p. 149.

9. Patil, A., Urban hydrology, need of India. Environ We Int J Sci Technol, 2015. 10: p. 29-36.

10. Rathnayke, U. and U. Srishantha, Sustainable urban drainage systems (SUDS)-what it is and where do we stand today? Engineering and Applied Science Research, 2017. 44(4): p. 235-241.

11. Park, K. and M.-H. Lee, The development and application of the urban flood risk assessment model for reflecting upon urban planning elements. Water, 2019. 11(5): p. 920.

12. Rangari, V.A., et al., Simulation of Urban Drainage System using a Storm Water Management Model (SWMM). Asian Journal of Engineering and Applied Technology, 2018. 7(S1): p. 710.

13. Ahamed, S.M.F. and S. Agarwal. Urban Flood Modeling and Management using SWMM for New RR Pet Region, Vijayawada, India. in International Conference on Advances in Civil Engineering (ICACE-2019). 2019.

14. Harsha, S.S., S. Agarwal, and C.H. Kiran, Urban Flood Modelling and Management using Storm Water Management Model. 2020.

15. Jato-Espino, D., et al., Coupling GIS with stormwater modelling for the location prioritization and hydrological simulation of permeable pavements in urban catchments. Water, 2016. 8(10): p. 451.

16. Broekhuizen, I., et al., Urban drainage models for green areas: Structural differences and their effects on simulated runoff. Journal of Hydrology X, 2019. 5: p. 100044.

17. Niazi, M., et al., Storm water management model: performance review and gap analysis. Journal of Sustainable Water in the Built Environment, 2017. 3(2): p. 04017002. 
18. Rossman, L.A., Storm water management model user's manual, version 5.0. 2010: National Risk Management Research Laboratory, Office of Research and ....

19. Rossman, L.A., Storm water management model user's manual. 2010, Version.

20. Gironás, J., et al., A new applications manual for the Storm Water Management Model(SWMM). Environmental Modelling \& Software, 2010. 25(6): p. 813-814.

21. Chowdhury, A., et al., Development of an Automatic Calibration Framework for Hydrologic Modelling Using Approximate Bayesian Computation. International Journal of Computer and Systems Engineering, 2016. 10(2): p. 119-126.

22. Luan, Q., et al., Runoff effect evaluation of LID through SWMM in typical mountainous, lowlying urban areas: A case study in China. Water, 2017. 9(6): p. 439.

23. Jang, S., et al., Using SWMM as a tool for hydrologic impact assessment. Desalination, 2007. 212(1-3): p. 344-356.

24. ASCE and W.E. Federation, Design and construction of urban stormwater management systems. ASCE Manuals and Rep. of Engineering Practice No. 77, WEF Manual of Practice FD20, 1992.

25. Council, A.S.o.C.E.U.W.R.R. Design and construction of urban stormwater management systems. 1992. ASCE.

26. Federation, W.E. and A.S.o.C. Engineers, Design and Construction of Urban Stormwater Management Systems. 1992, American Society of Civil Engineers and Water Environment Federation.

27. Peschke, G. and M. Kutilek, Infiltration model in simulated hydrographs. Journal of Hydrology, 1982. 56(3-4): p. 369-379. 